\title{
PENILAIAN KOMPETENSI SIKAP PADA MAHASISWA JURUSAN PPKN FIS UNIMA
}

\author{
Jan A. Rattu \\ Dosen Jurusan Pendidikan Pancasila dan Kewarganegaraan FIS UNIMA
}

\begin{abstract}
Abstrak
Tulisan ini bertujuan untuk memberikan deskripsi tentang: (1) Pentingnya penilaian kompetensi sikap, (2) Implementasi penilaian kompetensi sikap pada Mahasiswa Jurusan PPKn FIS Unima.

Berdasarkan hasil kajian berbagai literatur penulis menyimpulkan bahwa: a) Penilaian kompetensi sikap dalam pembelajaran PPKn merupakan hal yang patut dilaksanakan karena amanat dalam Undang-undang Nomor 10 Tahun 2003 tentang sistem pendidikan nasional, Permendikbud RI Nomor: 49 tahun 2014 tentang Standar Nasional Pendidikan Tinggi pasal 6:1, pasal 20:3, dan Panduan Akademik Universitas Negeri Manado edisi 2014 pasal 38 dan 39; b) Mahasiswa Jurusan Pendidikan Pancasila dan Kewarganegaraan (PPKn) merupakan sumberdaya manusia yang perlu dibekali dengan prilaku dan akhlak mulia sebagaimana diarahkan oleh falsafah hidup bangsa Indonesia yaitu Pancasila, sehingga dapat berperan sebagai warganegara yang efektif dan bertanggung jawab melalui mekanisme penilaian sikap; c) Implementasi penilaian sikap dalam bentuk observasi/pengamatan langsung dengan menggunakan program aplikasi. dan; d) Indikator penilaian sikap minimal meliputi: (1) Kompetensi spiritual, (2) Kompetensi kejujuran, (3) Kompetensi tanggung Jawab, (4) Kompetensi kerjasama, (5) Kompetensi Kesantunan dan (6) Kompetensi kepercayaan diri.
\end{abstract}

Kata Kunci: Penilaian Sikap, Implementasi Penilaian Sikap. 


\section{A. Pendahuluan}

Penilaian sikap dalam proses pembelajaran merupakan bagian yang tidak kala pentingnya dalam mengimplementasikan pendidikan karakter sebagai salah satu isyu sentral dalam pembangunan sumber daya manusia Indonesia, penilaian sikap menjadi hal yang penting ketika kita diperhadapkan pada kenyataan bahwa sebagai bangsa Indonesia kita telah memiliki sistem nilai luhur dalam Pancasila yang harus di implementasikan dalam sendi-sendi kehidupan berbangsa, bermasyarakat dan bernegara, artinya bahwa Pancasila telah disepakati menjadi sistem nilai, ideology, dasar Negara, pandangan hidup bahkan menjadi kepribadian bangsa, disamping itu Pancasila telah menjadi nilai-bilai relegi bangsa Indonesia yang menjunjung tinggi nilainilai kemanusiaan dan keadaban, dan mengedepankan nilai-nilai persatuan dan kesatuan bangsa, menghormati dan menjujung tinggi kedaulatan rakyat dengan mengembangkan kehidupan demokrasi serta menjunjung tinggi rasa keadilan dengan tidak membeda-bedakan suku, agama ras.

Di sisi yang lain dalam kasat mata kita diperhadapkan dengan kondisi nyata yang sangat memprihatinkan bahkan dapat mengarah pada terganggunya sendi-sendi kehidupan bangsa, masyarakat dan negara, terindikasi perilaku sebagian manusia Indonesia yang cendrung mengabaikan nilai-nilai; persatuan, kesatuan, kebersaman, cinta tanah air, hormati menghormati, menghargai perbedaan, menghargai hak-hak orang lain,

Kondisi-kondisi yang memprihatinkan ini semakin parah manakala dilakukan oleh orangorang-orang yang mengenyam dunia pendidikan formal apalagi sudah memperoleh gelar strata 1, strata 2, dan strata 3 , seperti yang dapat kita lihat prilaku oleh sebagian anggota DPRI melalui layar kaca TV, termasuk perilaku orang-orang yang berpredikat siswa, mahasiswa dalam melakukan aksi demonstrasi akhir-akhir ini yang mengarah pada tindakan anarkis, pemaksaan kehendak, dan tidak segansegan merusak barang milik iorang lain sarana prasarana kepentingan umum bahkan tindakan yang mengarah pada menghilangkan nyawa orang lain.
Detik News, Empat hal yang membuat Indonesia terancam jadi Negara gagal, 21 Juni 2012 dalam Syamsi Pasandaran "Paper seminar nasional penguatan pendidikan karakter melalui PPKn dalam mempersiapkan generasi tahun 2045, AP3KnI, Unima 17 Oktober 2014. "Kondisi-kondisi yang memprihatinkan ini, menempatkan Indonesia pada posisi yang mengkuatirkan. Pada Juli 2012 The Fund for Peace merilis indeks Negara terancam gagal tahun 2012. Indonesia menjadi salah satu Negara terancam gagal dengan total indeks 80,6 dan berada pada peringkat 63 dari 177 negara. Terdapat 4 (empat) indicator yang menempatkan Indonesia menjadi Negara terancam gagal yaitu; demografi, ketidak merataan pembangunan ekonomi, kekerasan terhadap minoritas serta ketidak mampuan Negara melindungi kelompok rentan, dan lemahnya aparat keamanan. Dijelaskan pula bahwa kondisi-kondisi seperti ini tentunya berimplikasi terhadap kurikulum program studi pendidikan kewarganegaraan di lembaga LPTK. Upaya untuk meningkatkan relevansi kurikulum PPKn di perguruan tinggi sudah harus dilakukan secara terus menerus. Upaya peningkatan relevansi itu mencakup relevansi materi dan bahan ajar, proses pembelajaran yang telah banyak mengalami pergeseran teoriteori belajar yang melatarinya. Penilaian hasil belajar yang secara spesifik mengukur perilaku etis dan sikap moral tentunya berbeda dengan penilaian terhadap aspek-aspek kognitif yang selama ini banyak mendominasi cara penilaian pendidikan karakter. (Syamsi Pasandaran 2014:3 "Paper seminar nasional penguatan pendidikan karakter melalui PPKn dalam mempersiapkan generasi tahun 2045, AP3KnI, Unima 17 Oktober 2014).

\section{B. Hakekat Penilaian Sikap \\ 1. Pengertian Sikap}

Menurut Peraturan Menteri Pendidikan dan Kebudayaan RI Nomor 49 tahun 2014 pasal 6 ayat 1 Tentang Standar Nasional Pendidikan Tinggi; menjelaskan Sikap sebagaimana dimaksud dalam Pasal 5 ayat (1) merupakan perilaku benar dan berbudaya sebagai hasil dari internalisasi dan aktualisasi nilai dan norma yang tercermin dalam 
kehidupan spiritual dan sosial melalui proses pembelajaran, pengalaman kerja mahasiswa, penelitian dan/atau pengabdian kepada masyarakat yang terkait pembelajaran. Teknik penilaian sikap terdiri atas observasi, partisipasi, unjuk kerja, tes tertulis, tes lisan, dan angket. (Permendikbud RI No 49 Tahun 2014 pasal 20:1).

Penilaian kompetensi Afektif berhubungan dengan minat dan sikap yang dapat membentuk tanggungjawab, kerjasama, disiplin, komitmen, dan percaya diri.

Sikap adalah sekelompok keyakinan dan perasaan yang melekat tentang objek tertentu dan kecenderungan untuk bertindak terhadap objek tersebut dengan cara tertentu (Calhoun \& Acocella, 1995). Menurut Sarwono (2002), sikap adalah kesiapan pada seseorang untuk bertindak secara tertentu terhadap hal-hal tertentu. Ajzen (1988) mendefinisikan sikap sebagai predisposisi yang dipelajari individu untuk memberikan respon suka atau tidak suka secara konsisten terhadap objek sikap. Respon suka atau tidak suka itu adalah hasil proses evaluasi terhadap keyakinan-keyakinan (beliefs) individu terhadap objek sikap (Fishbein \& Ajzen, 1975).

Baron dan Byrne (1997) mendefinisikan sikap sebagai penilaian subjektif seseorang terhadap suatu objek. Sikap adalah respon evaluative yang diarahkan seseorang terhadap orang, benda, peristiwa, dan perilaku sebagai objek sikap. Sikap melibatkan kecenderungan respon yang bersifat preferensial. Sikap sebagai respon evaluatif menunjukkan ekspresi suka atau tidak suka, setuju atau tidak setuju, mendekati atau menghindari, dan tertarik atau tidak tertarik terhadap objek sikap.

Cacioppo dkk (1986) berpendapat bahwa sikap adalah suatu evaluasi atau penilaian seseorang terhadap obyek sikap yang tercermin dalam bentuk perasaan setuju-tidak setuju, mendukung-tidak mendukung, sebagai potensi reaksi terhadap suatu obyek sikap. Sears dkk (1999) berpendapat bahwa sikap merupakan orientasi yang bersifat menetap dengan komponen-komponen kognitif, afektif dan perilaku. Komponen kognitif terdiri dari seluruh kognisi yang dimiliki seseorang mengenai objek sikap tertentu berupa fakta, pengetahuan dan keyakinan tentang objek. Sedangkan Komponen afektif menurut Stephan dan Stephan (1985) adalah komponen yang berkaitan dengan perasaan dan emosi seseorang terhadap objek sikap. Dan komponen perilaku merupakan kecenderungan seseorang untuk berperilaku sesuai dengan sikap yang ada pada dirinya.

Berdasarkan beberapa definisi yang telah dikemukakan oleh para ahli diatas, maka dapat disimpulkan bahwa sikap merupakan pandangan, perasaan dan kecenderungan seseorang bertindak terhadap objek sikap. (http://www.vedcmalang.com/pppptkboemlg/in dex.php/artikel-coba 2/edukasi/488-teori-teori sikap), diakses 19 Nopember 2014).

\section{Aspek-aspek Sikap}

Menurut Fishben \& Ajzen (1975), terdapat dua aspek pokok dalam hubungan antara sikap dengan perilaku, yaitu: 1). Aspek keyakinan terhadap perilaku. Keyakinan terhadap perilaku merupakan keyakinan individu bahwa menampilkan atau tidak menampilkan perilaku tertentu akan menghasilkan akibat-akibat atau hasil-hasil tertentu. Aspek ini merupakan aspek pengetahuan individu tentang objek sikap. Pengetahuan individu tentang objek sikap dapat pula berupa opini individu tentang hal yang belum tentu sesuai dengan kenyataan. Semakin positif keyakinan individu akan akibat dari suatu objek sikap, maka akan semakin positif pula sikap individu terhadap objek sikap tersebut, demikian pula sebaliknya. 2). Aspek evaluasi akan akibat perilaku. Evaluasi akan akibat perilaku merupakan penilaian yang diberikan oleh individu terhadap tiap akibat atau hasil yang dapat diperoleh apabila menampilkan atau tidak menampilkan perilaku tertentu. Evaluasi atau penilaian ini dapat bersifat menguntungkan dapat juga merugikan, berharga atau tidak berharga, menyenangkan atau tidak menyenangkan. Semakin positif evaluasi individu akan akibat dari suatu objek sikap, maka akan semakin positif pula sikap terhadap objek tersebut, demikian pula sebaliknya.

(http://www.vedcmalang.com/pppptkboemlg/in 
dex.php/artikel-coba 2/edukasi/488-teori-teori sikap, diakses 19 Nopember 2014).

\section{Implementasi Penilaian Sikap}

Penguatan proses pembelajaran dan komitmen melaksanakan penilaian sikap harus menjadi kebutuhan semua pihak baik sebagai dosen atau pun sebagai mahasiswa di lingkup jurusan PPKn FIS Unima dan menjadikan penilaian sikap sebagai suatu kebutuhan dalam proses penyiapan sumber daya manusia yang berdaya saing yang memiliki kecerdasan intelektual, sosial, spiritual maupun kinestetik, menyiapkan sumber daya manusia yang memiliki kecerdasan sosial dan spiritual inilah yang menjadi sasaran dalam pelaksanaan penilaian sikap.

Djahiri sebagaimana dikutip Dr. Apeles. Lexi Lonto, M.Si dan Theodorus Pangalila, S.Fil, M.Pd "Etika Kewarganegaraan" (2013:24) menyatakan bahwa nilai atau value berada dalam diri manusia (suara atau lubuk hati manusia), dengan acuan landasan atau tuntutan nilai moral tertentu yang ada dalam sistem nilai dan sistem keyakinan yang bersangkutan. Oleh karena itu nilai diartikan sebagai harga yang diberikan seseorang/sekelompok orang terhadap sesuatu. Harga ini menyangkut dunia afektif manusia.

Dr. Apeles. Lexi Lonto, M.Si dan Theodorus Pangalila, S.Fil, M.Pd "Etika Kewarganegaraan" (2013:25) menyatakan nilai merupakan suatu ide, konsep dan kepercayaan yang dijadikan patokan untuk menentukan pilihan dalam berfikir dan bertindak tentang sesuatu yang pantas atau tidak pantas

Menurut Adi Suryanto, dkk (2009:3.46) menyatakan bahwa ranah sikap yang perlu dikembangkan disekolah antara lain sikap siswa terhadap guru, mata pelajaran, dan sekolah. proses pembelajaran dikatakan berhasil apabila pihak sekolah mampu mengubah sikap siswa dari negative menjadi sikap positif.

Penilaian sikap yang objektif memang terasa sulit hal ini sebagaimana yang menjadi pengakuan dari guru-guru yang mengajar PPKn pada 12 (dua belas) sekolah yang menjadi lokasi observasi mahasiswa jurusan PPKn semester VII pada tanggal 14 Nopember 2014 di Kabupaten Minahasa, Kota Tomohon, dan Kota Manado, penilaian sikap menurut pengakuan guru-guru penilaian tersebut hanya di dasarkan pada ingatan mereka tentang sikap siswa tersebut hal ini disebabkan mereka sulit merumuskan indikatornya dan dari pengakuan mereka juga menunjukkan ketidak pahaman mereka terhadap penilaian sikap sebagimana tuntutan kurikulum tahun 2013. Tindakan seperti ini tentu sangat tidak efektif dalam menggambarkan kemampuan seseorang. Telah banyak penelitian tentang penilaian diranah afektif/sikap ini, namun kebanyakan menitik beratkan masalahnya pada penyiapan perangkat/instrument penilaian afektif tersebut. Sedangkan pada proses pelaksanaannya dilapangan belum terlihat adanya sistem untuk membantu memberikan nilai afektif secara objektif dan proporsional.

Berkaitan dengan itu Drs. Gembong Sumadiyono, M.Pd. merumuskan model penilaian sikap dalam bentuk aplikasi yang dapat memudahkan dalam pelaksanaannya sebagai berikut:

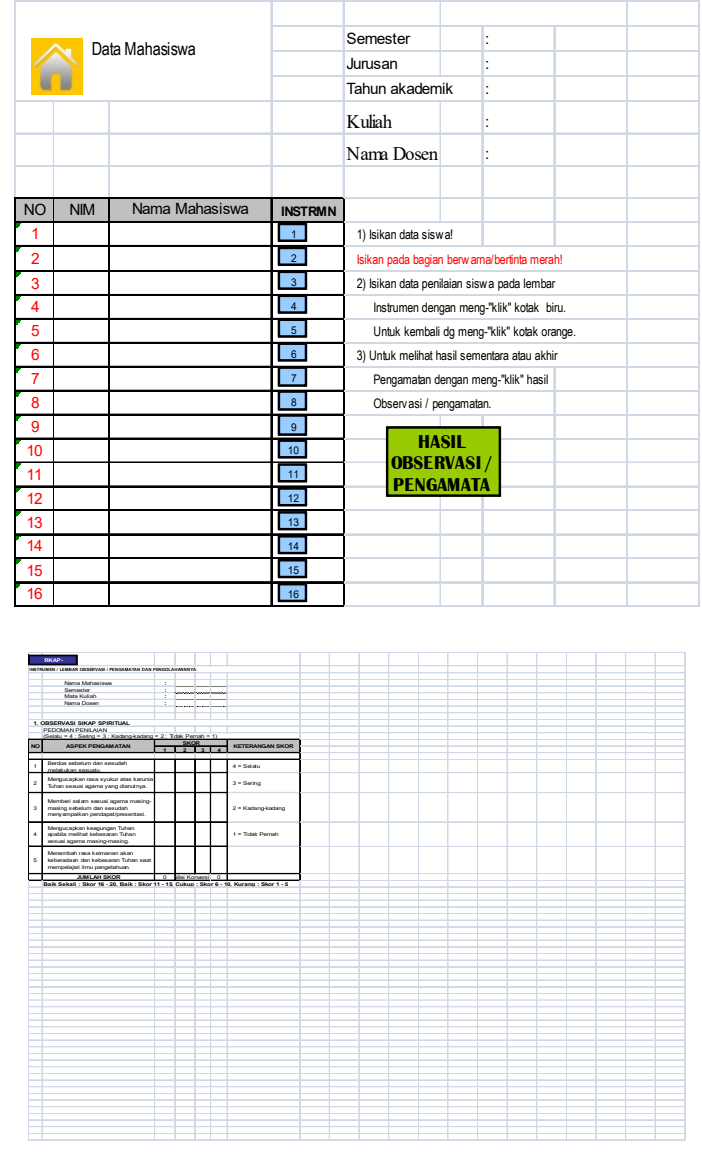


Jurnal Civic Education, Vol. 1 No. 1 Juni 2017

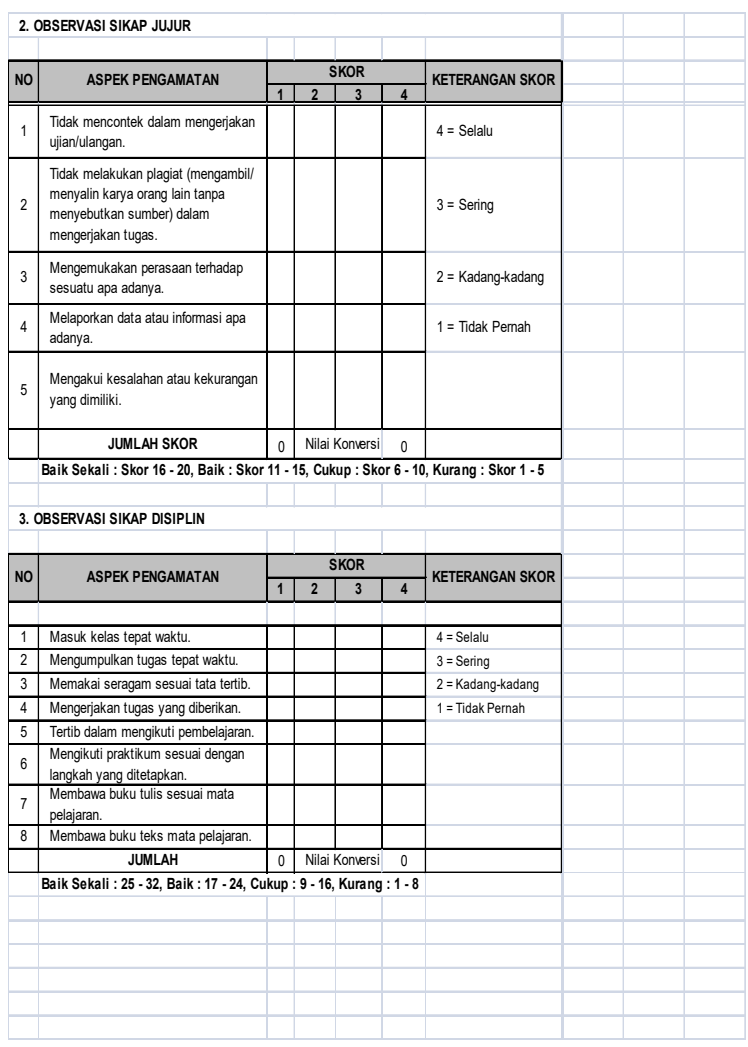

4. OBSERVASI SIKAP TANGGUNG JAWAB

\begin{tabular}{|c|c|c|c|c|c|c|}
\hline \multirow{2}{*}{ No } & \multirow{2}{*}{ ASPEK PENGAMATAN } & \multicolumn{4}{|c|}{ SKOR } & \multirow{2}{*}{ KETERANGAN SKOF } \\
\hline & & 1 & 2 & 3 & 4 & \\
\hline 1 & $\begin{array}{l}\text { Melaksanakan tugas individu dengan } \\
\text { baik. }\end{array}$ & & & & & $4=$ Selalu \\
\hline 2 & $\begin{array}{l}\text { Menerima resiko dari tindakan yang } \\
\text { dilakukan. }\end{array}$ & & & & & $3=$ Sering \\
\hline 3 & $\begin{array}{l}\text { Tidak menuduh orang lain tanpa bukti } \\
\text { yang akurat. }\end{array}$ & & & & & $2=$ Kadang-kadang \\
\hline 4 & Mengembalikan barang yang dipinjam. & & & & & $1=$ Tidak Pernah \\
\hline 5 & $\begin{array}{l}\text { Meminta maaf atas kesalahan yang } \\
\text { dilakukan. }\end{array}$ & & & & & \\
\hline & JUMLAH SKOR & 0 & i Kon & versi & 0 & \\
\hline
\end{tabular}

5. OBSERVASI SIKAP TOLERANSI

\begin{tabular}{|c|l|c|c|c|c|l|}
\hline \multirow{2}{*}{ NO } & \multicolumn{1}{|c|}{ ASPEK PENGAMATAN } & \multicolumn{3}{|c|}{ SKOR } & \multirow{2}{*}{ KETERANGAN SKOR } \\
\hline & & 1 & 2 & 3 & 4 & \\
\hline \hline 1 & Menghormati pendapat teman. & & & & & 4 = Selalu \\
\hline 2 & $\begin{array}{l}\text { Menghormati teman yang berbeda suku, } \\
\text { agama, ras, budaya dan gender. }\end{array}$ & & & & & \multirow{2}{*}{$3=$ Sering } \\
\hline 3 & $\begin{array}{l}\text { Menerima kesepakatan meskipun } \\
\text { berbeda dengan pendapatnya. }\end{array}$ & & & & & \multirow{2}{*}{2 = Kadang-kadang } \\
\hline 4 & Menerima kekurangan orang lain. & & & & & \multirow{2}{*}{$1=$ Tidak Pernah } \\
\hline 5 & Memaafkan kesalahan orang lain. & & & & & \\
\hline & JUMLAH SKOR & 0 & ii Konversi & & \\
\hline
\end{tabular}

Baik Sekali : Skor 16 - 20, Baik : Skor 11 - 15, Cukup : Skor 6 - 10, Kurang : Skor 1 - 5

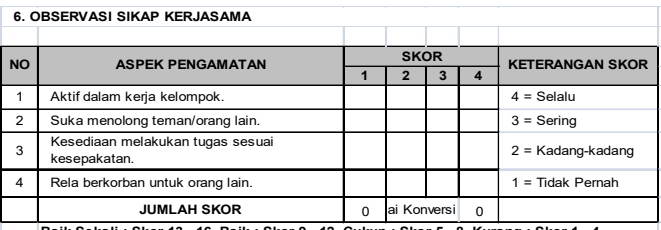

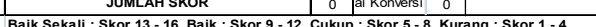

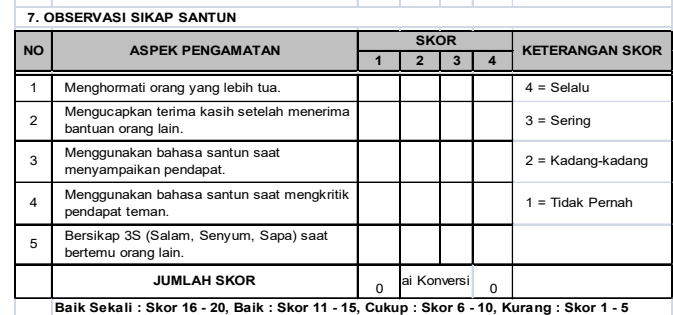

\begin{tabular}{|c|c|c|c|c|c|c|}
\hline \\
\hline \multirow{2}{*}{ No } & \multirow{2}{*}{ ASPEK PENGAMATAN } & \multicolumn{4}{|c|}{ SKOR } & \multirow{2}{*}{ KETERANGAN SKOR } \\
\hline & & & & 3 & 4 & \\
\hline 1 & Berani presentasi di depan kelas. & & & & & $4=$ Selalu \\
\hline 2 & $\begin{array}{l}\text { Berani berpendapat, bertanya, atau menjawab } \\
\text { pertanyaan. }\end{array}$ & & & & & $3=$ Sering \\
\hline 3 & $\begin{array}{l}\text { Berpendapat atau melakukan kegiatan tanpa } \\
\text { ragu-ragu. }\end{array}$ & & & & & $2=$ Kadang-kadang \\
\hline 4 & Mampu membuat keputusan dengan cepat. & & & & & $1=$ Tidak Pernah \\
\hline 5 & Tidak mudah putus asa/pantang menyerah. & & & & & \\
\hline & JUMLAH SKOR & 0 & ai Ko & iversi & 0 & \\
\hline
\end{tabular}




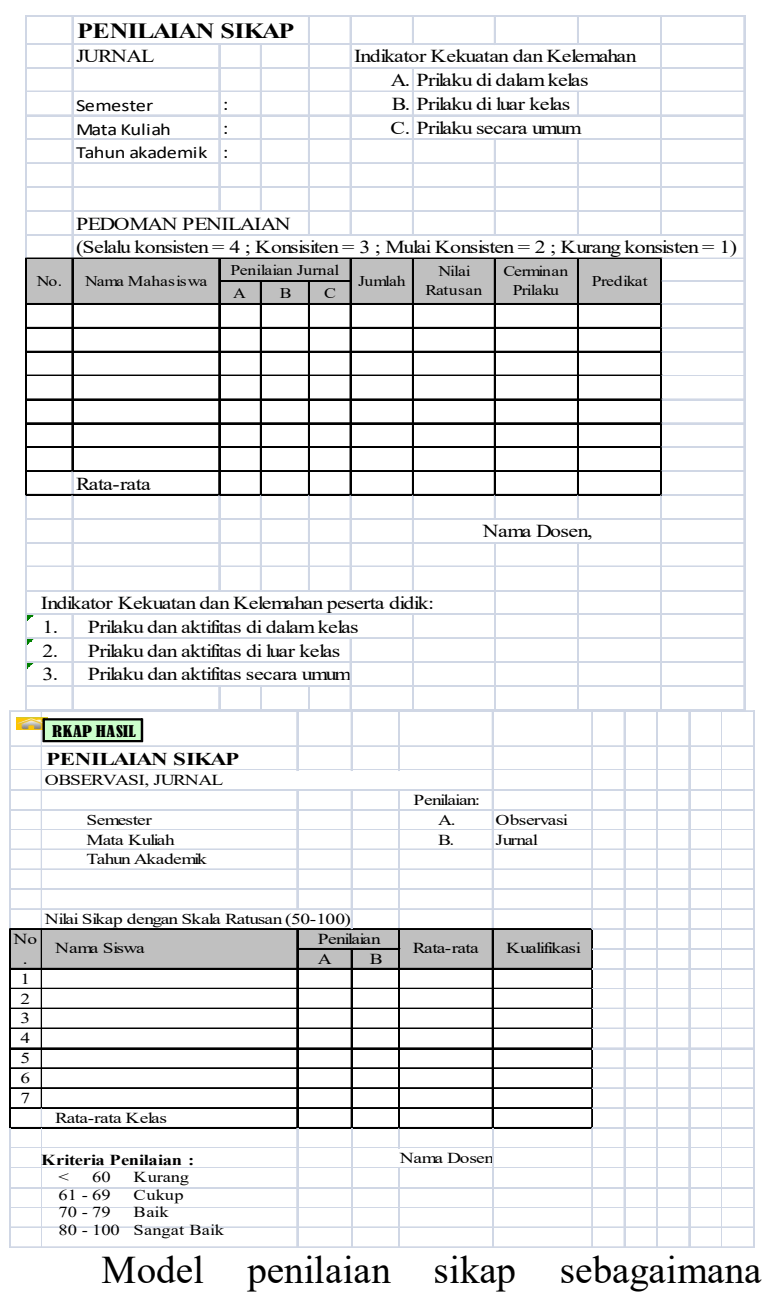
tersebut diatas tentu sangat diharapkan akan mempermudah dalam implementasi penilaian sikap oleh guru ataupun dosen terutama guru yang mengajar PPKn ataupun dosen yang mengajar pada mahasiswa jurusan PPKn oleh karena format-format tersebut sudah dirancang dalam bentuk aplikasi.

\section{Penutup}

Kunci keberhasilan dalam pelaksanaan penilaian sikap sangat tergantung dari komitmen dan rasa tanggungjawab semua pihak sebagai guru ataupun dosen, yang dilandasi oleh adanya kesadaran bahwa sumber daya manusia yang berdaya saing tidak sekedar memilki kompetensi kognitif tapi lebih dari pada itu juga memiliki kompetensi sikap, perilaku yang baik.

Kesulitan dalam mengimplementasikan penilaian sikap terutama dalam penyiapan format dan pengisiannya solusinya adalah melalaui pemahaman dan pengembangan program aplikasi penilaian sikap sebagaimana yang telah dijelaskan sebelumnya yang pada prinsipnya hanya ditekankan pada kegiatan pengisian data pada table observasi dan Jurnal sedangkan penentuan rata-rata dan kualifikasi dalam bentuk aplikasi.

\section{Daftar Pustaka}

Apeles Lexi Lontoh, dan Theodorus Pangalila, 2013 "Etika Kewarganegaraan. Yogyakarta, Ombak

Adi Suryanto. Dkk.2009. Evaluasi Pembelajaran, Universitas Terbuka Jakarta.

Gembong Sumadiyono, 2014. "File Prrogram Aplikasi Penilaian Sikap, Pengetahuan dan Ketrampilan dalam rangka sosialisasi kurikulum tahun 2013 lingkup pengawas sekolah, Jakarta,

http://www.vedcmalang.com/pppptkboemlg/ind ex.php/artikel-coba 2/edukasi/488-teoriteori sikap, diakses 19 Nopember 2014.

Laporan hasil observasi dokumen pembelajaran guru PPKn, mahasiswa jurusan PPKn FIS Unima pada 12 (dua belas) Sekolah di Kabupaten Minahasa, Kota Tomohon dan Manado 14 Nopember 2014

Pasandaran Syamsi, 2014 Paper seminar nasional pendidikan karakter melalui PKn dalam mempersipakan generasi emas tahun 2045, AP3KnI, Unima. hhtp//news.detik.com/read. detik news empat hal yang membuat Indonesia terancam jadi Negara gagal, 21 Juni 2012, dalam Pasandaran Syamsi Paper seminar nasional pendidikan karakter melalui PKn dalam mempersipakan generasi emas tahun 2045, AP3KnI, Unima.

Peraturan Menteri Pendidikan dan Kebudayaan Nomor 49 tahun 2014 Tentang Standar Nasional Pendidikan Tinggi pasal 6 ayat 1 